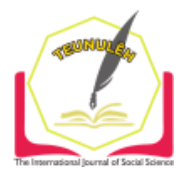

Jurnal IImiah Teunuleh

The International Journal of Social Sciences

Vol. 2, Issues. 4, Des 2021

P-ISSN: 2807-193X | E-ISSN: 2746-4393

\title{
COMMUNITY AWARENESS NOT TO ACTIVATE IN THE RED ZONE OF MT. SINABUNG ERUPTION
}

\author{
Muhammad Fahmi Siregar ${ }^{1}$; Arief Wahyudi ${ }^{2}$; Sri Hadiningrum ${ }^{3}$; Fazli \\ Rachman"; Reh Bungana Beru Perangin-angin'; Prayetno6; Majda El Muhtaj"; \\ Yusna Melianti ${ }^{8}$ \\ 1-8, Universitas Negeri Medan \\ 4fazli.rachman@unimed.ac.id
}

\begin{abstract}
This study aims to photograph public awareness not to move in the red zone of the eruption of Mount Sinabung. Although the government has relocated victims of the eruption of Mount Sinabung and forbade people to carry out activities in the red zone of Mount Sinabung until now there are still many people who are active in the red zone area. The research is empirical legal research. The location of this research was in Gamber Village, Subdistrict of Simpang Empat, Karo Regency. Data that was collected will be analyzed by technique qualitative analysis. The people of Gamber village carry out activities in the red zone of Mount Sinabung consciously due to several factors. first, economic factor; second, the factor of agricultural land; and third, the belief factor. In addition to the three main factors, the government's inability to persuade its people persuasively not to carry out activities in the red zone also contributes to the violation of red zone policies. Looking at the various factors mentioned above, there are inefficient ways that can encourage people to maintain what is in effect.
\end{abstract}

Keywords: Awareness, Community, Sinabung, Eruption, Red Zone

\section{A. Introduction}

Beginning in 2010, the Mount Sinabung eruption has lasted more than a decade and continues to this day (Perangin-angin, Rachman, Prayetno, Siregar, \& Muhtaj, 2021). The eruption has a broad impact on Sinabung social community. In addition to volcanic ash in large quantities, the eruption of Mount Sinabung also spewed hot clouds. Hot cloud bursts from Mount Sinabung can take place dozens of times a day (Molana, 2021; Nurwihastuti, Astuti, Yuniastuti, Perangin-Angin, \& Simanungkalit, 2019b; Perangin-angin et al., 2021; Pranita, 2021). 
Vol. 2, Issues. 4 , Des 2021

P-ISSN: 2807-193X | E-ISSN: 2746-4393

Muhammad Fahmi Siregar; Arief Wahyudi; Sri Hadiningrum; Fazli Rachman; Reh Bungana Beru

Perangin-angin; Prayetno; Majda El Muhtaj; Yusna Melianti

The eruption of Mount Sinabung poses primary threats and secondary threats to the community. The primary threats are hot clouds, lava flows, incandescent rock throws or avalanches, and volcanic ash. Meanwhile, the secondary threat is in the form of lava flows (Nurwihastuti, Astuti, Yuniastuti, \& Perangin-angin, 2019; Perangin-angin et al., 2021). The threats posed by the eruption of Mount Sinabung caused people who were directly affected by the eruption to be placed in refugee camps.

In addition to having to evacuate, thousands of community members have also lost their homes and/or agricultural land. To reduce disaster risk for victims of the eruption of Mount Sinabung, the government carried out relocation for the community of several villages. The relocation was carried out in 3 stages (Nurwihastuti, Astuti, Yuniastuti, \& Perangin-angin, 2019; Perangin-angin et al., 2021). This effort is early mitigation of the eruption of Mount Sinabung, based on the recommendation of the Center for Volcanology and Geological Hazard Mitigation regarding the red zone area of Mount Sinabung (Tempo.co, 2017).

Although the government has relocated victims of the eruption of Mount Sinabung, The government has also prohibited people from carrying out activities in the red zone of Mount Sinabung. However, there are still many people who are active in the red zone area (Perangin-angin et al., 2021). The portrait of public awareness not to move in the red zone of Mount Sinabung becomes interesting to record. Awareness is a time when someone understands and cares about doing and obeying something (Hastjarjo, 2005).

Awareness is the product of thought (Jamanti, 2014). Awareness has several meanings (a) shared knowledge; (b) internal belief; (c) the mental state of being aware of something; (d) recognize one's actions or feelings; (e) personal unity, namely the totality of impressions, thoughts, feelings that make up a conscious feeling; and ( $f$ ) normal wakefulness (Hastjarjo, 2005). Therefore, to make changes in society, the first step to make it happen is to change the way people think (Jamanti, 2014). Awareness is the result of the way of thinking of a group of people, each thought is separate from the other (Simorangkir, 1987). Everyone's awareness is part of collective human awareness (community). This means that if you want a change in society, you have to change something in yourself (Jamanti, 2014). 


\section{B. Method}

The research on community awareness not to activate in the red zone of Mt. Sinabung eruption is empirical legal research. Empirical legal research analyzes and examines how the law is working in society. It is mentioned with legal sociology research or field research (Efendi \& Ibrahim, 2020). The subject that is studied in empirical legal research is Legal Behavior. It is real behaviour from a person or community that is related to the common norm in society (Salim \& Nurbani, 2013). Meanwhile, the examine object in this research is law compliance of the community.

The location of this research was in Gamber Village, Subdistrict of Simpang Empat, Karo Regency. Research data contain both primary and secondary data. Primary data is data that is collected directly from the first resources. Secondary data includes official documents, books, and research results in the form of reports (Amiruddin \& Asikin, 2018). Data that was collected will be analyzed by technique qualitative analysis. Qualitative data analysis is carried out in three ways, namely, data systematization (descriptive method), explanation (explicative), and improvement and renewal (prescriptive or normative method) (Butarbutar, 2018). Qualitative analysis was carried out by taking into account the facts in the field and combined with secondary data obtained from the literature. The results of the analysis are presented descriptively so that a description of the results of the research is descriptive qualitative (Butarbutar, 2018).

\section{Finding and Discussion}

The people of Karo Regency are mostly farmers. No less than $75 \%$ of the people of Karo Regency work as farmers. Therefore, Karo is one of the regencies that produces various types of agricultural products such as vegetables, fruits, flowers, seeds and so on, the largest in North Sumatra (Bukit \& Sembiring, 2013; Pemerintah Kabupaten Karo, n.d.). These agricultural products are to meet the food needs of the province of North Sumatra, especially the city of Medan and its surroundings.

Starting on August 27, 2010, the eruption of Mount Sinabung is still ongoing. The eruption of Mount Sinabung has an impact on various aspects of the life of the people of Karo regency. Mount Sinabung emits volcanic ash, cold lava and hot clouds that result in fatalities (Nurwihastuti, Astuti, Yuniastuti, \& Perangin-angin, 2019; Nurwihastuti, Astuti, Yuniastuti, Perangin-Angin, \& Simanungkalit, 2019a; Perangin-angin et al., 2021). Therefore, to avoid increasing casualties, the government has set a red zone at a radius 
of $3 \mathrm{~km}$ from the peak of Mount Sinabung. The red zone is an area designated as a dangerous area in the event of an eruption, therefore people are prohibited from carrying out activities within the area designated as a red zone (Maxriz, 2018).

The policy of determining the red zone causes several villages to be included in the territory of the zone. Communities whose villages are included in the red zone are required to leave the village to move and look for housing outside the red zone, either in the form of temporary or permanent housing. Every family head who leaves his house and land will receive compensation or be relocated to a place provided by the government (Perangin-angin et al., 2021). For those who have been relocated, they have obtained agricultural land and simple houses. The relocated people have obtained agricultural land and simple houses.

Currently, the policy on determining the red zone has not been revoked, therefore the public is prohibited from carrying out activities within the zone. The fact is that people no longer heed the prohibition, and are active in the red zone. Especially people who work as farmers and depend on agricultural products. Although the relocated villagers do not return to their homes in the red zone, their agricultural activities are still ongoing. Not infrequently when residents are still on their agricultural land, at the same time Mount Sinabung erupts.

Activities in the red zone area are a violation of a predetermined policy. These violations they do knowingly. The public knows that the red zone is a dangerous area for the eruption of Mount Sinabung, so they are not allowed to do activities in it. But society has no other better option (Maxriz, 2018). There are several efforts made by the local government so that people do not enter and carry out activities in the red zone. These efforts include: blocking access to the red zone by installing portals at the entrance to the red zone; conducting counselling; putting up posters containing appeals not to be active in the red zone area of Mount Sinabung; and providing cash compensation to or relocation.

Even though it has been banned, residents are still active in the red zone of the eruption of Mount Sinabung. Violations committed by the community are motivated by several factors, including: first, economic factor. People who mostly work as farmers, and whose main source of income is from agricultural products, are forced to go back to farming. They continue to farm even though their agricultural land is in the red zone (Maxriz, 2018; Perangin-angin et al., 2021). All daily necessities, children's education costs, and capital for farming (managing agricultural land) again come from agricultural 
products. The community tries to study the phenomenon of the eruption of Mount Sinabung, so they can understand what to do if an eruption occurs while on their agricultural land. People try to make friends with the eruption of Mount Sinabung.

Second, the factor of agricultural land. For farmers, agricultural land is the main factor for farming besides seeds and fertilizers. Without land, farmers cannot do much because it is on that land that they manage the land to grow crops and produce their agricultural products. For the people of Gamber village - one of the villages included in the red zone area of Mount Sinabung - it is the people who get compensation during relocation, the funds can only buy houses to live in, they cannot buy agricultural land to grow crops. The absence of agricultural land forced the farmers from the village of Gamber to return to their lands which were in the red zone area. They carry out farming activities on their respective lands. This will be very risky if Mount Sinabung erupts. The people of Gamber village are very aware of the dangers that will befall them if they are in the red zone. However, for them, there is no other choice because agricultural land is the heart of life for farmers.

The third, the belief factor. For the people of Gamber village, nowadays people believe that they are "friends" with Mount Sinabung. What is meant by friendship is that the community is very familiar with Mount Sinabung; recognize the early symptoms when Mount Sinabung will be active; recognize the level of danger from the activities of Mount Sinabung. With this belief, the people of Gamber village dare to do activities in the red zone of Mount Sinabung.

The three main factors above have given rise to the courage of the community to continue their activities in the red zone of Mount Sinabung. Although the activity of Mount Sinabung has not stopped, people are still active in the red zone, and there is no increase in casualties due to the eruption.

People who are active on red zone land, will take care of each other and remind each other in the event of an eruption. They do this so that there are no fatalities. They are very aware that if there is a loss of life, the red zone will be guarded by the local government, security forces from both the TNI-Polri and the community will be prohibited from entering to farm. The ineffectiveness of the policy is due to the lack of support from various sociological factors in the village community (Rosana, 2014; Soekanto, 1977).

In addition to the three main factors, the government's inability to persuade its people persuasively not to carry out activities in the red zone also contributes to the 
Vol. 2, Issues. 4 , Des 2021

P-ISSN: 2807-193X | E-ISSN: 2746-4393

Muhammad Fahmi Siregar; Arief Wahyudi; Sri Hadiningrum; Fazli Rachman; Reh Bungana Beru

Perangin-angin; Prayetno; Majda El Muhtaj; Yusna Melianti

violation of red zone policies. Looking at the various factors mentioned above, there are inefficient ways that can encourage the community to maintain the applicable regulations (Hasibuan, 2014). The prospect of law enforcement against the policy of establishing the red zone is predicted to be very difficult to enforce (Hasibuan, 2014), given the activity of Mount Sinabung which remains active until now. The government's ability to relocate and or provide adequate compensation has not been able to meet the minimum standards of community needs, especially farmers so that the omission of policy violations will continue.

\section{Conclusion}

The people of Gamber village doing activities in the red zone of Mount Sinabung consciously are a violation of the law and risk the safety of their lives. The factors that made these violations occur include economic actors, agricultural land factors and the belief that the community is friendly with Mount Sinabung. In addition, the government failed to convince the public not to do activities in the red zone of Mount Sinabung.

\section{Bibliography}

Amiruddin, \& Asikin, Z. (2018). Pengantar Metode Penelitian Hukum (Revision). Jakarta: P.T. RajaGrafindo Persada.

Bukit, I. M., \& Sembiring, S. A. (2013). Analisis Potensi Ekspor Hasil-hasil Pertanian di Kabupaten Karo. Jurnal Ekonomi Dan Keuangan, 1(5), 18-29.

Butarbutar, E. N. (2018). Metode Penelitian Hukum Langkah-Langkah Untuk Menemukan Kebenaran Dalam IImu Hukum. Bandung: Refika Aditama.

Efendi, J., \& Ibrahim, J. (2020). Metode Penelitian Hukum Normatif dan Empiris. Jakarta: Kencana.

Hasibuan, Z. (2014). Kesadaran Hukum Dan Ketaatan Hukum Masyarakat Dewasa Ini. Publik, 1(2), 78-92. https://doi.org/10.31604/justitia.v1i01.\%25p

Hastjarjo, D. (2005). Sekilas Tentang Kesadaran (Consciousness). Buletin Psikologi, 13(2), 79-90. https://doi.org/10.22146/bpsi.7478

Jamanti, R. (2014). Pengaruh Berita Banjir di Koran Kaltim Terhadap Kesadaran Masyarakat Kelurahan Temindung Permai Samarinda. EJournal IImu Komunikasi, 2(1), 17-33.

Maxriz, J. (2018). Analisis Faktor Penyebab Masyarakat Desa Guru Kinayan Tetap Bertahan di Zona Merah Gunung Sinabung. Tunas Geografi, 7(2), 107-114. 
https://doi.org/10.24114/tgeo.v7i2.12231

Molana, D. H. (2021). Gunung Sinabung Erupsi, 40 Desa Terdampak Hujan Vulkanik. Retrieved March 2, 2021, from news.detik.com website: https://news.detik.com/berita/d-5478036/gunung-sinabung-erupsi-40-desaterdampak-hujan-abu-vulkanik

Nurwihastuti, D. W., Astuti, A. J. D., Yuniastuti, E., \& Perangin-angin, R. B. B. (2019). Pengurangan Risiko Bencana Erupsi Gunung Sinabung. Yogyakarta: Elmatera.

Nurwihastuti, D. W., Astuti, A. J. D., Yuniastuti, E., Perangin-Angin, R. B. B., \& Simanungkalit, N. M. (2019a). Volcanic hazard analysis of sinabung volcano eruption in karo north sumatra indonesia. Journal of Physics: Conference Series, 1175(1), 1-5. https://doi.org/10.1088/1742-6596/1175/1/012186

Nurwihastuti, D. W., Astuti, A. J. D., Yuniastuti, E., Perangin-Angin, R. B. B., \& Simanungkalit, N. M. (2019b). Volcanic Hazard Analysis of Sinabung Volcano Eruption in Karo North Sumatra Indonesia. Journal of Physics: Conference Series, 1175(1), 12186. IOP Publishing.

Pemerintah Kabupaten Karo. (n.d.). Potensi Pertanian. Retrieved December 27, 2021, from www.karokab.go.id website: https://www.karokab.go.id/id/potensidaerah/pertanian/674-potensi-pertanian

Perangin-angin, R. B. B., Rachman, F., Prayetno, Siregar, M. F., \& Muhtaj, M. El. (2021). Responses of Communities Affected by the Sinabung Eruption to COVID-19: A Human Rights-Based Review. In B. Sinaga, H. Fibriasari, \& J. Rajagukguk (Eds.), Proceedings of the 3rd International Conference on Innovation in Education, Science and Culture, ICIESC 2021, 31 August 2021, Medan, North Sumatera Province, Indonesia (pp. 434-439). https://doi.org/10.4108/EAl.31-82021.2313813

Pranita, E. (2021). Fakta Erupsi Gunung Sinabung Hari Ini, 13 Kali Semburan Awan Panas. Retrieved March 2, 2021, from www.kompas.com/ website: https://www.kompas.com/sains/read/2021/03/02/184500023/7-fakta-erupsigunung-sinabung-hari-ini-13-kali-semburan-awan-panas?page=all

Rosana, E. (2014). Kepatuhan Hukum Sebagai Wujud Kesadaran Hukum Masyarakat. Jurnal Tapis: Jurnal Teropong Aspirasi Politik Islam, 10(1), 61-84. https://doi.org/10.24042/tps.v10i1.1600

Salim, H. S., \& Nurbani, E. S. (2013). Penerapan Teori Hukum Pada Penelitian Tesis dan Disertasi. Jakarta: P.T. RajaGrafindo Persada.

Simorangkir, O. P. (1987). Kesadaran Pikiran dan Tanggung Jawab. Jakarta: Yagrat.

Soekanto, S. (1977). Kesadaran Hukum dan Kepatuhan Hukum. Jurnal Hukum \& Pembangunan, 7(6), 462-170. https://doi.org/10.21143/jhp.vol7.no6.742

Tempo.co. (2017, August). Warga di Sekitar Sinabung Diminta Tak Masuki Zona Merah. Tempo.Co. Retrieved from https://nasional.tempo.co/read/896625/warga-di- 
Vol. 2, Issues. 4, Des 2021

P-ISSN: 2807-193X | E-ISSN: 2746-4393

Muhammad Fahmi Siregar; Arief Wahyudi; Sri Hadiningrum; Fazli Rachman; Reh Bungana Beru Perangin-angin; Prayetno; Majda El Muhtaj; Yusna Melianti

sekitar-sinabung-diminta-tak-masuki-zona-merah 